Г. М. Віняр

\title{
НОВИЙ ПРЕФІКСОЇД У СЛОВОТВІРНІЙ СИСТЕМІ УКРАЇНСЬКОЇ МОВИ
}

Віняр Г. М. Новий префіксоїд у словотвірній системі української мови.

У статті розглянуто значення й словотвірну структуру нових слів 3 префіксоїдом нано-, що виник у сфері природничих наук і завдяки мовним та позамовним чинникам набуває активного використання в різних сферах. Простежено появу й розвиток нової лексико-морфеми квантитативної семантики, засвідчено глобалізаційні тенденції в її використанні.

Ключові слова: префіксоїд, похідне слово, термінологічна лексика, дериваційний засіб. 
Виняр А. Н. Новый префиксоид в словообразовательной системе украинского языка.

В статье рассмотрены значение и словообразовательная структура новых слов с префиксоидом нано-, возникшим в сфере естественных наук и благодаря лингвистическим и экстралингвистическим факторам распространившимся в различных сферах. Отслежено появление и развитие новой лексикоморфемы квантитативной семантики, определены глобализационные тенденции в ее использовании.

Ключевые слова: префиксоид, производное слово, терминологическая лексика, деривационное средство.

Winyar A. M. The new lexical prefix in the Ukraine word-formative system.

The meaning and the word-formative structure of new words with the lexical prefix нано- created in the sphere of natural sciences and spread in other spheres owing to linguistic and extralinguistic factors are considered. The appearance and the development of the new morpheme with quantitative semantic are followed up, globalizing tendencies in its use are detected.

Key words: lexical prefix, derivative word, terminological vocabulary, derivative means.

Серед препозитивних елементів, які за останні півстоліття набули значної словотвірної активності, виділяється група префіксоїдов квантитативної семантики: моно-, бi-, полі-, мікро-, макро-, міні-, максі, що характеризуються значною абстрагованістю значення. Свого часу мовознавці багато уваги приділили питанню статусу таких словоелементів, дослідженню ступеня їх словотвірної активності [1; 4; 5]. На думку К. Г. Городенської, іншомовні елементи 3 кількісно-оцінним значенням мають найвищий ступінь префіксоїдності через їх здатність до десемантизації [5, с. 41].

Відповідно до поглиблення процесів наукового пізнання дійсності з'являються мовні засоби, покликані адекватно відбивати нові грані наукового пошуку. Так, за останне десятиліття набула словотвірної активності лексико-морфема нано-. «Великий тлумачний словник сучасної української мови» визначає нано- таким чином: приставка, яка у складі слова означає $10^{-9}($ н), тобто одна мільярдна частина чогось [2, с. 725]. У виданні цього словника за 2009 рік 3 аналізованим префіксоїдом зафіксовано 11 лексем, 2 з яких (нанорельєф, нанометр) наявні у словниках, виданих до початку XXI століття. Нові лексеми з префіксоїдом нано-, зафіксовані у «Великому тлумачному словнику сучасної української мови», $\epsilon$ термінами (нанодіагностика, нанофієтоз), передусім на позначення одиниць виміру: наноампер, нановат, наногенрі, нанокулон, наноом, наносекунда, нанотесла, нанофарад.

Як зазначено в «Словнику іншомовних слів» (2000р.), нано 3 грецької перекладається як «карлик», тому в медицині ненормально низький, карликовий зріст, що $є$ наслідком порушення функції залоз внутрішньої секреції, називають нанізм, або наносомія. Названі терміни, як і наноскопія, засвідчують функціонування аналізованої морфеми як кореневої - у якості твірної основи, а не префіксоїда.

На сьогодні префіксоїд нано- найбільш продуктивний у фізичній термінології (наночастинки, наносистеми, наноматеріали), проте нанотехнології вже захоплюють нові сфери науки і практики: нанотовари, нанопослуги. 
У публікаціях науково-педагогічних видань останніми роками префіксоїд нано- активно використовується для творення нової термінологічної лексики, оскільки саме він об'єктивно відбиває пошуки науковців, спрямовані на пізнання матерії вглиб. Так, стаття доктора філософії К. Корсака своїм заголовком визначає: Наносуспільство найбільш обгрунтована назва суспільства XXI століття (Вища школа, 2008, №12, с. 90). Найбільш частотним у публікаціях науковців є термін нанотехнологї: Нанотехнологї - цее сукупність методів виробництва об'єктів живої й неживої природи із заданою атомною структурою шляхом цілеспрямованого маніпулювання атомами й молекулами (Вища школа, 2008, №12, с. 95). Оскільки йдеться про футурологічні прогнози, то зазначений термін ще не усталився, не набув необхідної для термінологічної лексики визначеності: Експерти чомусь не звернули увагу на стан $i$ найближчі (не кажучи про віддалені) перспективи нанотехнологій, тому використали ией термін виключно для опису очікуваного прогресу у сфері комп'ютерних процесорів, де мікронні елементи вже стали поступатися значно мениим, які мають розміри 30 60 нм $\left(1 \mathrm{\mu м}=10^{-9}\right.$ м) (Вища школа, 2008, №12, с.90).

Пошук у Google за словом нанотехнологї дав понад 5 млн. результатів російською та українською мовами, а пошук за англійським відповідником Nanotechnology - понад 20 млн., що свідчить про глобальне використання названого терміна в міжнародному масштабі. За даними «Вікіпедії», нанотехнологіями (рос. нанотехнологии, англ. nanotechnologies, неім. Nanotechnologien), інша назва наномолекулярні технологіï, в широкому значенні слова прийнято називати міждисциплінарну галузь фундаментальної і прикладної науки, у якій вивчаються закономірності фізичних і хімічних систем протяжністю в декілька нанометрів або часток нанометра (нанометр - це одна мільярдна частка метра або, що те ж саме, одна мільйонна частка міліметра (діаметр людської волосини становить близько 80 тис. нанометрів) [3].

Нанотехнологї, нанонауки - це наука і технологія колоїдних систем, це колоїдна хімія, колоїдна фізика, молекулярна біологія, мікроелектроніка. Принципова відмінність колоїдних систем, до яких належать хмари, кров людини, молекули ДНК і білків, транзистори, 3 яких збираються мікропроцесори, у тому, що поверхня таких частинок або величезних молекул у мільйони разів перевершує обсяг самих частинок, такі частки займають проміжне положення між справжніми гомогенними розчинами, сплавами, і такими звичайними об'єктами макросвіту, як стіл, книга, пісок. Поведінка таких систем дуже відрізняється від поведінки iстинних розчинів, розплавів i від об'єктів макросвіту завдяки високорозвиненій поверхні, як правило, такі ефекти починають відігравати значну роль, коли розмір частинок лежить у діапазоні 1-100 нанометрів, 
звідси прийшло заміщення слова колоїдна фізика, хімія, біологія на нанонауки і нанотехнології, з огляду на розмір об’єктів, про які йде мова.

Вужче значення цього терміна прив'язує нанотехнології до розробки матеріалів, приладів та інших механічних і немеханічних пристроїв, у яких застосовуються подібні закономірності. Нанотехнології мають справу 3 процесами, які протікають в просторових сферах нанометрових розмірів. Тобто, нанотехнологї можна означити як технології, грунтовані на маніпуляції окремими атомами і молекулами для побудови структур iз наперед заданими властивостями. $€$ думка, що у світі немає на сьогоднішній день стандарту, що таке нанотехнології, що таке нанопродукція. У Сврокомісії створена спеціальна група, якій дали два роки на те, щоб розробити класифікацію нанопродукції [3].

Використання префіксоїда нано- у творенні нової лексики набуло в українській мові стрімкого зростання, твірні основи таких похідних не обмежені сферою точних наук. Про глобальність позамовних чинників такої активності свідчить поява терміна нанореволючія. Наприклад: Для уважних $і$ неупереджених спостерігачів за всіма світовими подіями в науково-технологічних та виробничо-забезпечувальних сферах уже на зламі сторіч стали очевидними настання безпрецедентно важливої для виживання людства чергової революиії в засадах його стосунків $з$ природним середовищем і використання ресурсів біосфери. За відсутності узгодженої міжнародної назви иієї револючэї пропонуємо одразу кілька авторських варіантів: нанореволюція, четверта хвиля, квантова, ноосферна тощзо (Вища школа, 2008, №12, с. 90). Як твірна база для похідних $з$ формантом нано- залучаються не тільки іншомовні основи, але й власне українські: Використання чималої кількості старих джерел $i$ неувага до найновіших завадили А. Свідзинському помітити появу великої групи нанорозділів природничих наук, молодого й динамічного сектора товарів 6-го i 7-го технологічних укладів (нанотехнології, найбільи імовірно, складуть основу 7-го і 8-го укладів), «багатомільярдних» економічних проектів у США, Свропейському Союзі, Японії, Росії (Вища школа, 2008, №12, с. 91); Не випадково наш відомий педагог-науковеизь I. Підласий також, ігноруючи нанонауки, зробив наприкінці 2007 року такий висновок (Вища школа, 2008, №12, с. 92).

Твірні основи, що сполучаються 3 префіксоїдо нано-, здебільшого є назвами неістот на позначення абстрактних понять: Ocb $i$ E. Дрекслер відзначився надто примітивним передбаченням, адже його пропозиція лікувати людей способом уведення в капіляри «підводних човнів 3 нанорозмірами» $\epsilon$ точним аналогом пропозиції XIX століття використовувати весла для пересування людей у повітрі (Вища школа, 2008, №12, с. 97). Поєднання 3 твірними основами, що мають конкретне значення, менш продуктивне: Лиме у США Е. Дрекслер розгорнув 
кампанію $з$ пропаганди роботів-«наноасамблерів», але вона мала обмежений вплив на решту планети (Вища школа, 2008, №12, с. 91).

Але значення нових похідних аналізованої структури не обмежується назвами неістот: Нанофутуролог Е. Дрекслер пророкує, щзо нанотехнологї кардинально змінять не тільки сфери суспільства, але й сам біологічний вид Ното Sapiens, замінивши його новим біотехнологічним видом, щзо само розвивається - Nano Sapiens (Вища школа, 2008, №12, с. 96); Нині для виробництвва перших з отриманих щзе років 20 тому справжніх нанопродуктів - сферичних вуглечевих фулеренів використовуються звичайнісінькі індустріальні технологї, щуо супроводжуються значними шкідливими викидами в довкілля (Вища школа, 2008, №12, с. 96).

Регулярність сполучення аналізованого префіксоїда 3 твірними основами практично не обмежена їхнім значенням і походженням, у ролі твірних часто виступають українські основи (нанорозмір, нанорозділ), що свідчить про адаптацію цього словотвірного засобу до нашої мови. Аглютинативність таких препозитивних елементів дозволяє мовцям згортати в однослівні оказіональні новотвори значні за обсягом конструкції: новина зі сфери нанотехнологій - «наноновина»; тема дослідження нанотехнологій - «нанотема». Напр.: Віднайдення реального шляху до штучного фотосинтезу - найважливіша $i$ найвагоміша «наноновина» останніх двох років (Вища школа, 2008, №12, с. 98). Або: ...На наших теренах «нанотема» майже не звучить в освітній, політичній, економічній та науковій сферах, на відміну від розвинених держав Заходу i Сходу, та навіть Росії (Вища школа, 2008, №12, с. 91). Або: Ми пропонуємо в усій «наносфері» раз $i$ назавжди домовитися про те, щзо не всі способи виготовлення дуже малих продуктів автоматично слід називати «нанотехнологіями» (Вища школа, 2008, №12, с. 96).

Актуальність наукових досліджень в наносфері очевидна, що сприятиме формуванню окремого масиву термінів 3 лексико-морфемою нано-. Зважаючи на новизну аналізованих термінів, довкола доцільності їх вживання в певному значенні серед науковців точаться дискусії: ... У той час навіть у спеціалізованих наукових часописах лише зрідка з'являлися терміни «наноматеріали» (переважно йшлося про фулерени) і щзе рідше «нанотехнологї̈ (Вища школа, 2008, №12, с.91).

Зростання арсеналу препозитивних дериваційних засобів 3 кількісним значенням, у свою чергу, свідчить про автономізацію префіксоїдного оформлення нових слів, а значить виокремлення в ще один спосіб морфологічного словотвору.

\section{Література}

1. Богдан М. М. Одна з продуктивних моделей словотвору сучасної мови / М. М. Богдан // Українська мова і література в школі. - 1968. - №11. - С. 28-30.

2. Великий тлумачний словник сучасної української мови / [уклад. і голов. ред. В. Т. Бусел]. - К. ; Ірпінь : ВТФ «Перун», 2009. - 1736 с. 
3. Вікіпедія [Електронний ресурс] / Режим доступу : http://uk.wikipedia.org/wiki/.

4. Віняр Г. М. Розвиток системи дериваційних засобів на базі кореневих морфем / Г. М. Віняр // Вісник Житомирського педагогічного університету. - Житомир, 2004. - Вип. 14. - С. 210-214.

5. Городенська К. Г. Префікси і префіксоїди в українській мові / К. Г. Городенська // Мовознавство. 1986.- №1. - С. 36-41.

6. Наносистеми, наноматеріали, нанотехнології / Щоквартальний збірник наукових праць / Том 9, вип. 1. - К. : РВВ ІМФ, 2011. - 274 с.

7. Словник іншомовних слів / Упорядник Л. І. Пустовіт. - К. : 2000. 